\title{
100 years later: the dark heritage of the Great War at a prisoner-of-war camp in Czersk, Poland
}

\section{Dawid Kobiałka*}

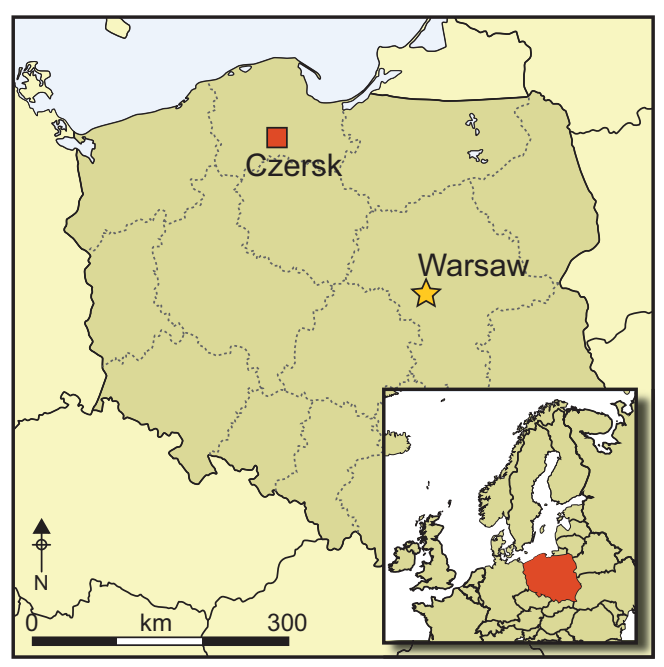

Archaeological research into twentiethcentury global conflicts has understandably focused on sorrow, pain and death when interpreting the associated material, structural and human remains. There are, however, other approaches to studying 'difficult' (or 'dark') heritage, which reveal that such heritage may have a bright side. This study discusses a Russian canteen recovered from the German First World War prisoner-of-war camp at Czersk in Poland. Discovered in 2006, the canteen belonged to a Russian prisoner. It records biographical details of its owner, and offers an alternative narrative of difficult heritage by testifying to emotion and human creativity behind barbed wire.

Keywords: Poland, Czersk, First World War, dark heritage, trench art

\section{Introduction}

Archaeology is the study of material culture of any period, no matter its age. Archaeologies of the First World War, the Second World War or even the Cold War are acknowledged branches of contemporary archaeological research (e.g. Saunders 2007; Moshenska 2013; Hanson 2016). Archaeology, it is argued, not only documents, contextualises and enriches historical narratives concerning the recent past (González-Ruibal 2014). Through meticulous analysis of material culture and landscape transformations, the archaeologist is also able to offer alternative interpretations of allegedly well-known events, places and even entire landscapes (Passmore et al. 2014). It could even be suggested that the archaeologies of twentieth-century material culture are now among the most dynamically developing fields of archaeological research (Holtorf \& Piccini 2009).

* Institute of Archaeology and Ethnology, Polish Academy of Sciences, al. Solidarności 105, 00-140 Warsaw, Poland (Email: dawidkobialka@wp.pl) 
Polish archaeologists have studied the material culture and landscapes related to the First and Second World Wars. Indeed, Poland is rich in such material remains. The most important research (and of broadest social outreach) has been that led by Andrzej Kola (2005) at Katyn and Kharkiv. That research aimed to locate and exhume bodies, and reclaim memories of Polish officers killed by the NKVD (the Soviet secret police) during the Second World War in modern Russia and Ukraine. For Polish archaeology, the methodology, research aims and problems offered by this study became a dominant model of archaeological inquiry into the recent past. The research had two implications of particular importance.

First, Kola draws research attention to the archaeological value of twentieth-century remains in Poland. Kola uses a diversity of archaeological approaches into the recent past and applies them to explore the archaeology of martyrdom. Hence, much Polish archaeological research within the context of the Second World War focuses on death and concentration camps, and mass graves or the graves of those killed by the Communists after the Second World War. Second, many single and mass graves were intentionally hidden in woodlands, as was the case at Katyn and Kharkiv.

Archaeological research into twentieth-century military heritage is becoming increasingly popular among Polish archaeologists, as evidenced by three recently published books. The first is a synthesis of field research at the Brus firing ground, where archaeologists searched for the bodies of people killed by the German and Soviet forces (Głosek 2010). In the second, edited by Ławrynowicz and Żelazko (2015), many of the contributors assume that archaeology of the recent past concerns the reclamation of memories, identities, bones and material culture of those killed by the German and Soviet forces. Here, the contributing authors reduce the complexity and multivocality of archaeological research of twentieth-century material heritage to the archaeology of totalitarianism. Finally, the last work in this context is An archaeology of contemporary times (Zalewska 2016), which discusses general archaeological research on twentieth-century conflict heritage. These studies undoubtedly represent research on so-called 'difficult' or 'dark' heritage.

The concept of difficult heritage has an impressive body of literature from various disciplines (Macdonald 2009). Historians, philosophers and anthropologists have analysed the concept from different angles, and dark heritage is one of the most popular aspects of tourist studies (Logan \& Reeves 2009; Biran et al. 2011). The remains of concentration and death camps and mass graves comprise some of the most disturbing examples of dark heritage of the recent past. They are also the main subject of archaeological research on the recent past in Poland (e.g. Kola 2005; Głosek 2010; Ławrynowicz \& Żelazko 2015; Zalewska 2016). Indeed, it can be claimed that such research is focused almost entirely on difficult heritage.

Such a diverse issue-approached from various theoretical perspectives-lacks a single definition. For the purpose of the present study, however, the following definition may serve:

[difficult heritage is] a past that is recognised as meaningful in the present but that is also contested and awkward for public reconciliation with a positive, self-affirming 
contemporary identity. 'Difficult heritage' may also be troublesome because it threatens to break through into the present in disruptive ways (Macdonald 2009: 1).

To simplify, dark heritage research is the narration of death, the killing of innocent people, forced labour, pain and sorrow, with the aim of reclaiming memories, identities, heritage and stories of some of the victims. As Kola's work has shown, such archaeological research has crucial social and cultural implications. Nonetheless, the point here is simple: the narration of dark heritage is one among many possible approaches that archaeology can take in studying and interpreting the material heritage of the recent past. It is an oversimplification to understand dark heritage research as a narrative focused solely on death, martyrdom and sorrow (Kobiałka et al. 2015). Archaeological research concerning dark heritage in the UK and Belgium is, for example, much more diverse (e.g. Schofield 2005; Stichelbaut \& Cowley 2016).

Accordingly, and in contrast to Kola (2005), it is claimed here that the archaeology of the recent past (particularly of recent conflicts) is not the archaeology of martyrdom. It is a far more complex, diverse and sophisticated branch of archaeological research (Stichelbaut et al. 2017). For example, the archaeologies of guilt and shame in relation to the recent past aim at approaching the multi-faceted nature of dark heritage (Tarlow 2012). These indicate another crucial perspective that is often overlooked in the context of conflict archaeology: the significance of the range of human emotions memorialised in material culture. In other words, analysing dark heritage facilitates the discovery of human fears, worries and hopesamong others.

This paper aims to offer a more complex understanding of dark heritage, using a prisonerof-war (POW) camp at Czersk in Poland as a case study. This site was chosen as a case study for two reasons. First, it is an unusual example of a Polish Great War site; Second World War heritage has received much more attention in Polish archaeology. It is as if material heritage of the Great War was of less archaeological value than that dating to the Second World War. Second, this is a place where thousands of POWs lost their lives. It is therefore an example of difficult heritage for local communities. A Russian canteen found at the camp and dating to the Great War, however, offers an alternative insight into this dark heritage. The canteen is a material memory of human love and an example of outstanding creativity behind barbed wire (an issue discussed by Carr and Mytum (2012)). In other words, dark heritage also has its own bright side.

\section{A POW camp at Czersk as difficult heritage}

Great War POW camps are usually forgotten relics of the recent past and are now systematically disappearing; they occupy a liminal space between cultural memory and oblivion. This is definitely the case for the camps located in modern Poland. To date, even historical research on these camps has been scarce, with the exception of the camp in Tuchola (Karpus \& Rezmer 1997). The centenary of the outbreak of the Great War has increased interest in the archaeological value of this type of heritage (e.g. Rola et al. 2015). One of the German POW camps was Kriegsgefangenenlager Czersk (Figure 1), operational between 1914 and 1918. The site has been of scientific interest to the author and colleagues since 2015; the history and archaeology of the camp and preliminary research results have (C) Antiquity Publications Ltd, 2018 


\section{Kriegsgefangenealagar Czersk, Westpr. \\ Gefongene Busen tragen Hols zum Baraolonbau susemmon}

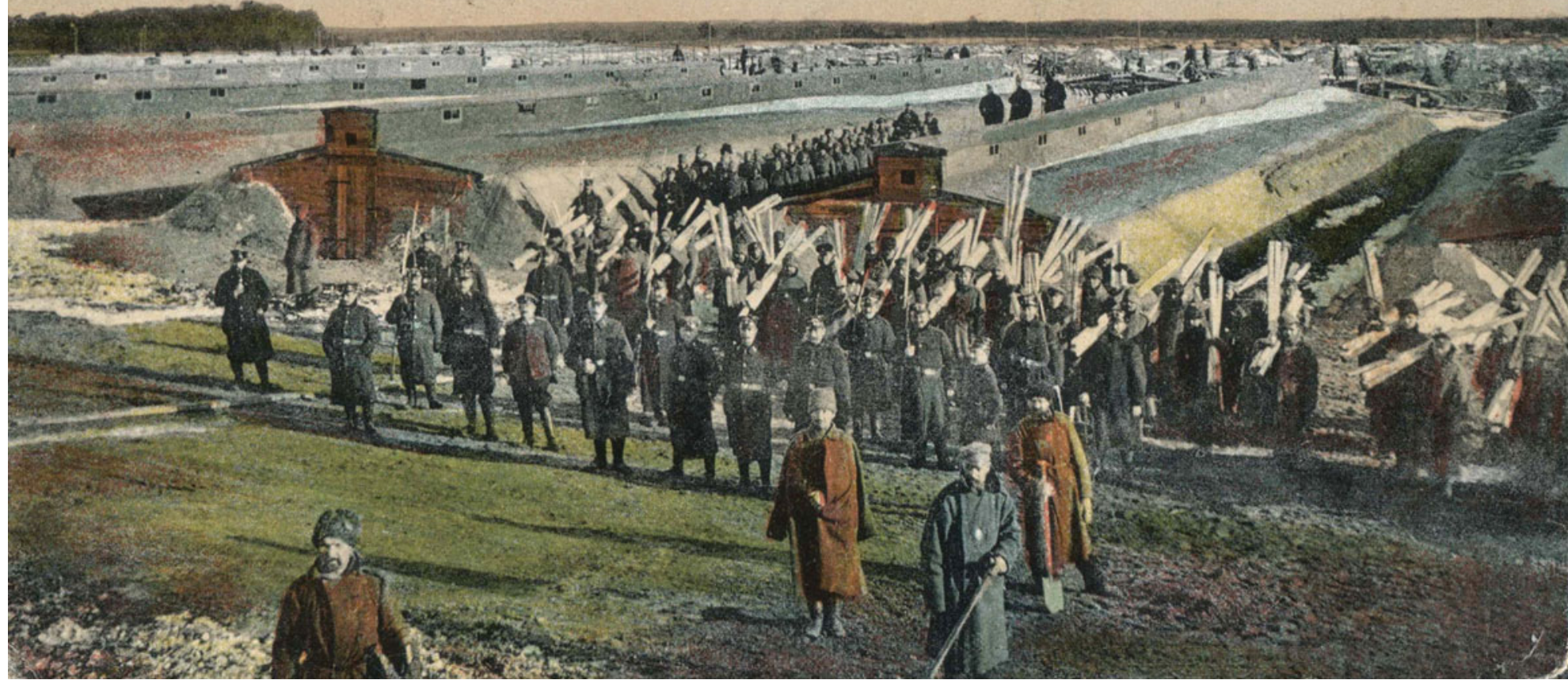

Figure 1. A German propaganda postcard showing the camp in Czersk (Dawid Kobiatka's private archive). 


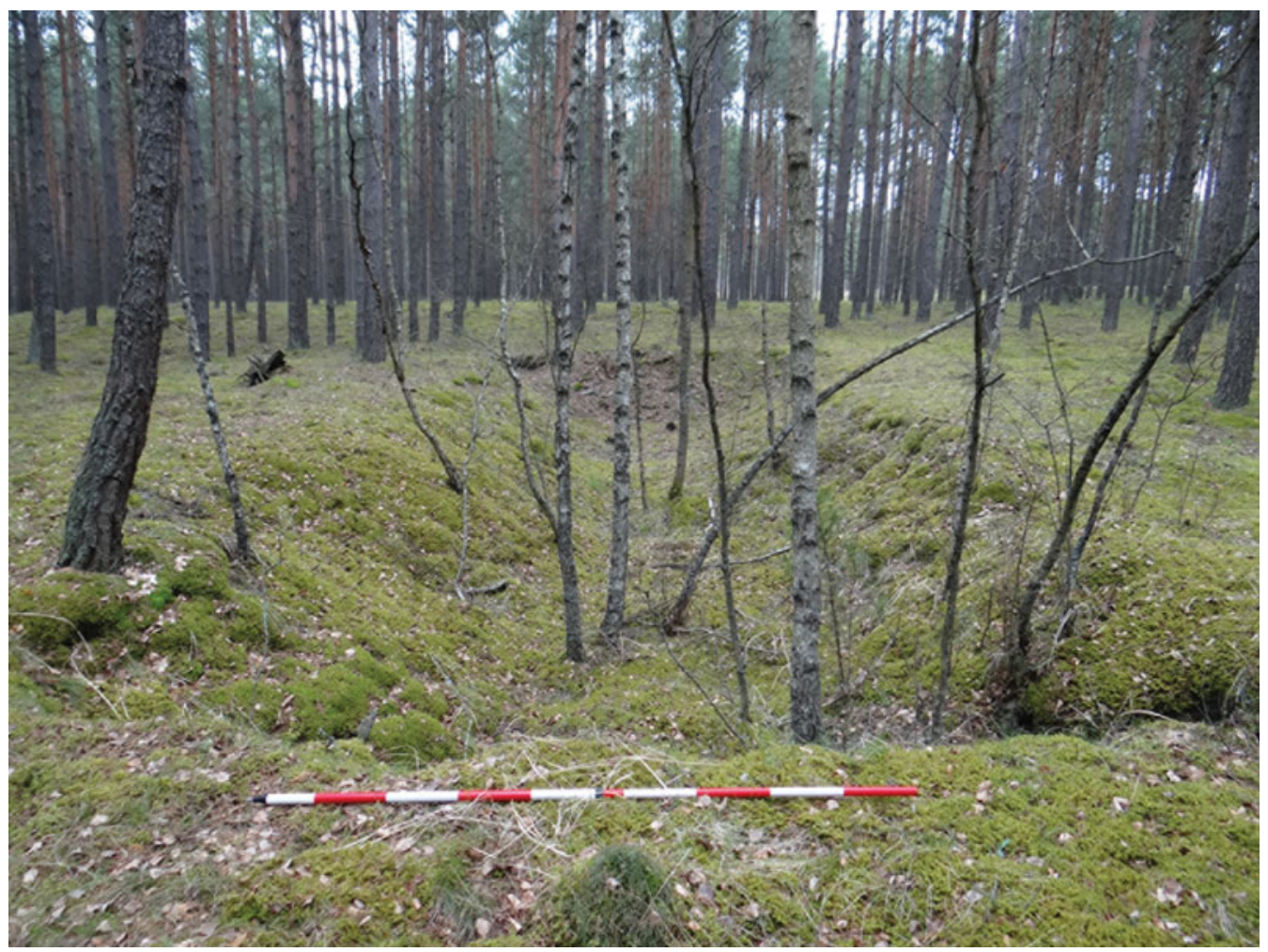

Figure 2. Remains of one of the features at the camp in Czersk (photograph: Dawid Kobiatka).

already been published (Kobiałka et al. 2017). Only the aspects of the camp's past that are relevant to the issue of difficult heritage are therefore highlighted here.

Although mostly Russian and Romanian soldiers were detained in Czersk, historical documents confirm that a small number of French, Italian, Portuguese and English soldiers were also imprisoned here. The camp functioned for the entire war and was closed and dismantled a few weeks after 11 November 1918 (Armistice Day). Today, most of the landscape of the previous camp is forested (Figure 2). Using LiDAR technology, however, it was possible to document part of the camp landscape (Hesse 2010) (Figure 3).

The most evocative and distressing remnant of this dark heritage is the associated POW cemetery. This could be considered a cultural and natural forest: a forest of concrete crosses that mark mass graves, between which have grown pines and birches (Figure 4). Due to brutal treatment by the guards, insufficient rations, infectious diseases and forced labour, thousands of prisoners never left the camp. One prisoner later claimed:

I was captured with the entirety of Eight Company at Ciechanow. We were immediately transported in cattle trucks to Czersk, where we were unloaded at the camp. After that we were forced to log the woodland, where our future dug-outs were to be built. Until then, we slept outdoors on the bare ground. After a few days, most of us had large bleeding wounds on our hands, which resulted in painful blisters. We were not able to hold shovels and axes in our hands [author's translation] (Chełminiak 1999: 14).

(C) Antiquity Publications Ltd, 2018 


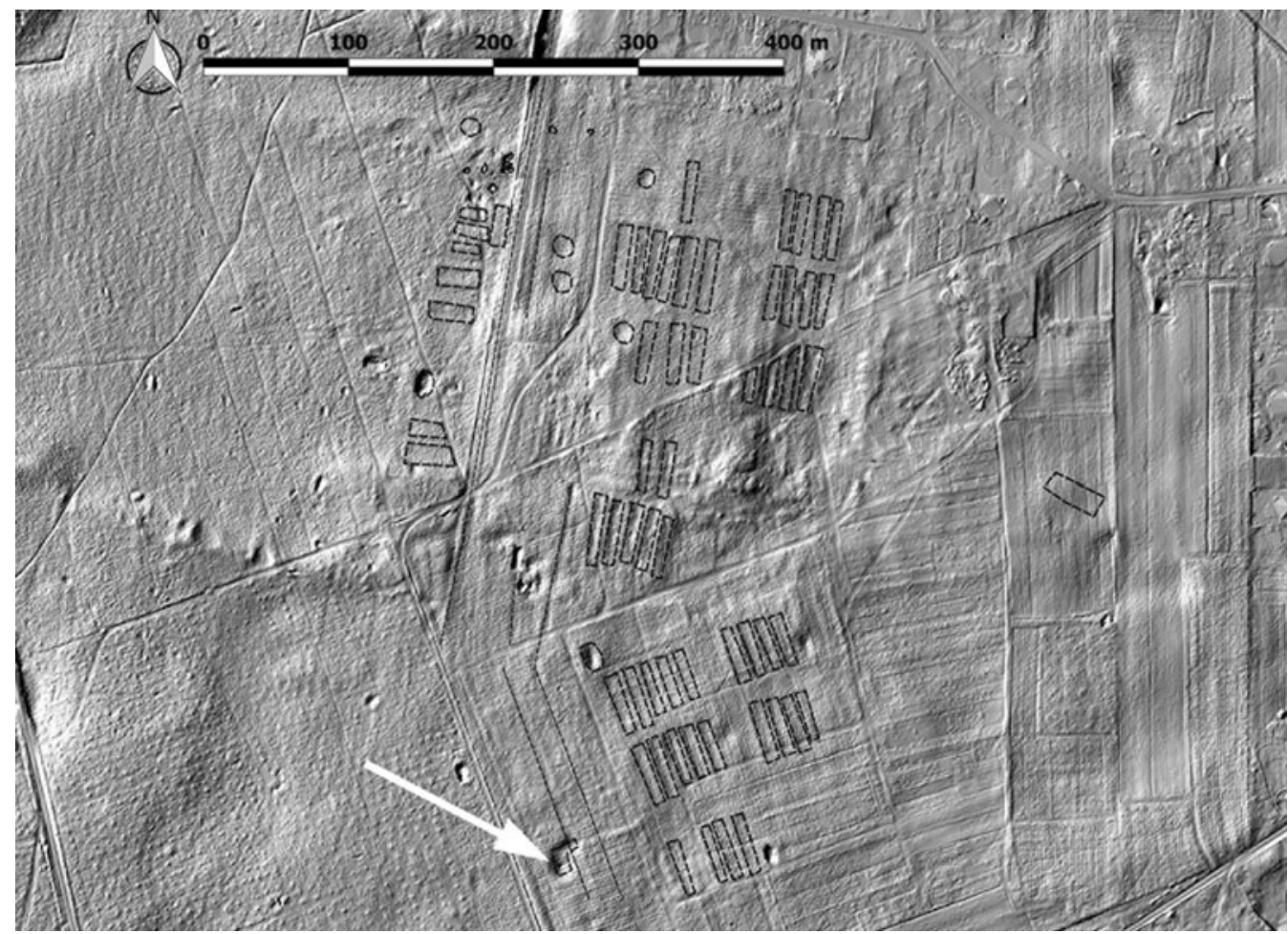

Figure 3. A 'northern part' of the camp in Czersk, visible on LiDAR derivatives. The arrow indicates a feature where an artefact analysed in this article was found (prepared by Mikotaj Kostyrko and Dawid Kobiatka).

There are different estimates for the exact number of prisoners who died at Czersk and were buried at the cemetery. Some researchers claim that as many as 8503 soldiers lost their lives in the Czersk camp (Karpus \& Rezmer 1997: 19), whereas recent research suggests a figure between 4988 and 4993 (Marcinkiewicz 2016).

It is no surprise that after the end of the Great War, local communities had difficulty in deciding how to cope with such heritage; the camp was a locus where terrible things took place, an embodiment of the sorrow and death of thousands of people (Chełminiak 1999). The cemetery was also problematic: it was a site where other soldiers (e.g. Russian, Romanian, French, Italian, Portuguese and British) were buried, not ours (Polish). Finally, prisoners were also forced labourers-essentially slaves-who were rented by local people of Czersk and neighbouring villages to work for them. The development and welfare of Czersk village was built upon the pain, blood and sweat of the prisoners. These seem to be among the reasons why the cemetery and remains of the camp have been left to decay and are vanishing from local memory. Even the exact location of the camp was unknown until recently. Archaeological research has now reclaimed some of these memories (Kobiałka et al. 2017). Yet even in such dark and traumatic heritage as the Czersk camp, something affirmative can be discerned: a small, aluminium Russian canteen offers a different insight into dark heritage. 


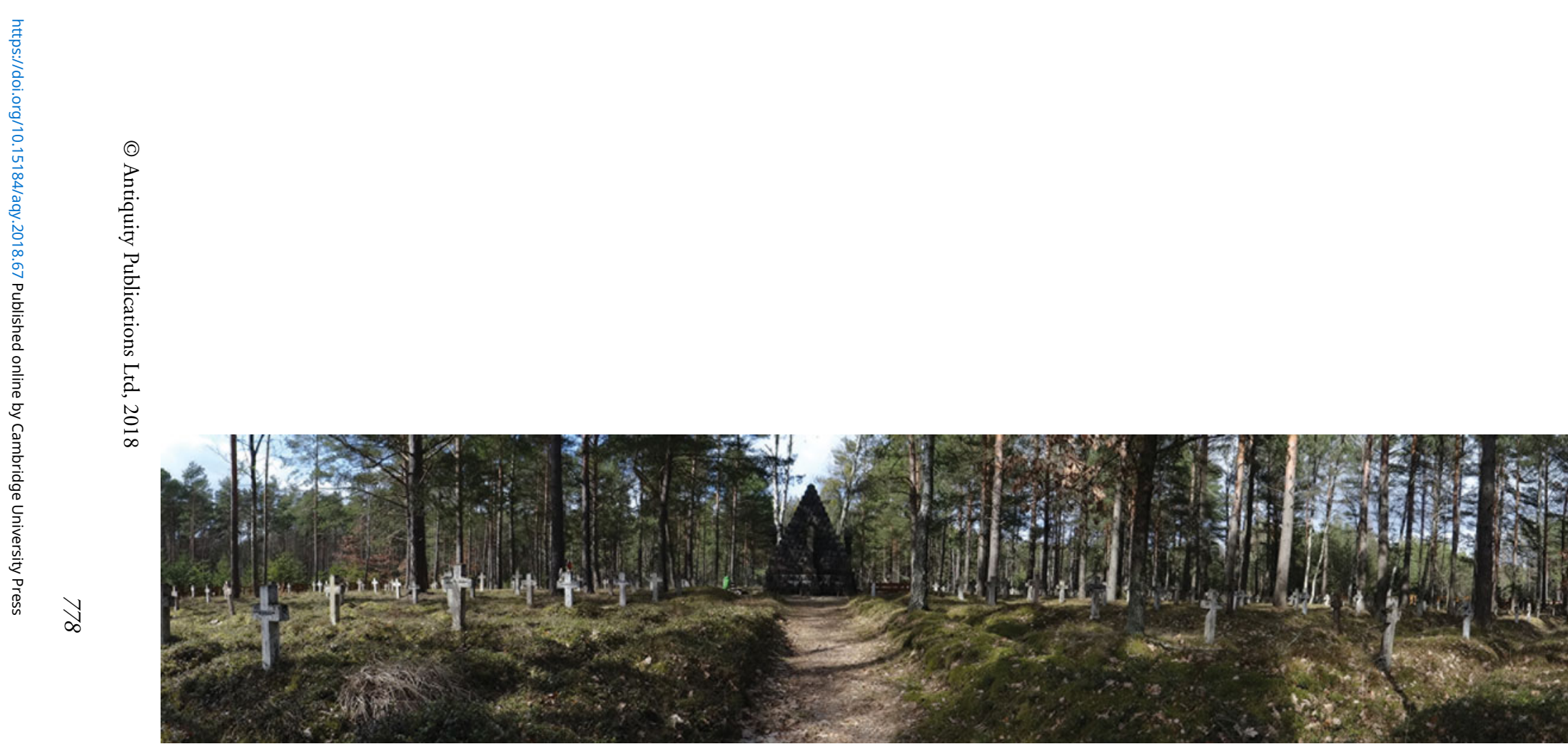

0
है
$\frac{2}{2}$
$\frac{2}{2}$

Figure 4. A POW cemetery in Czersk (photograph: Dawid Kobiatka). 


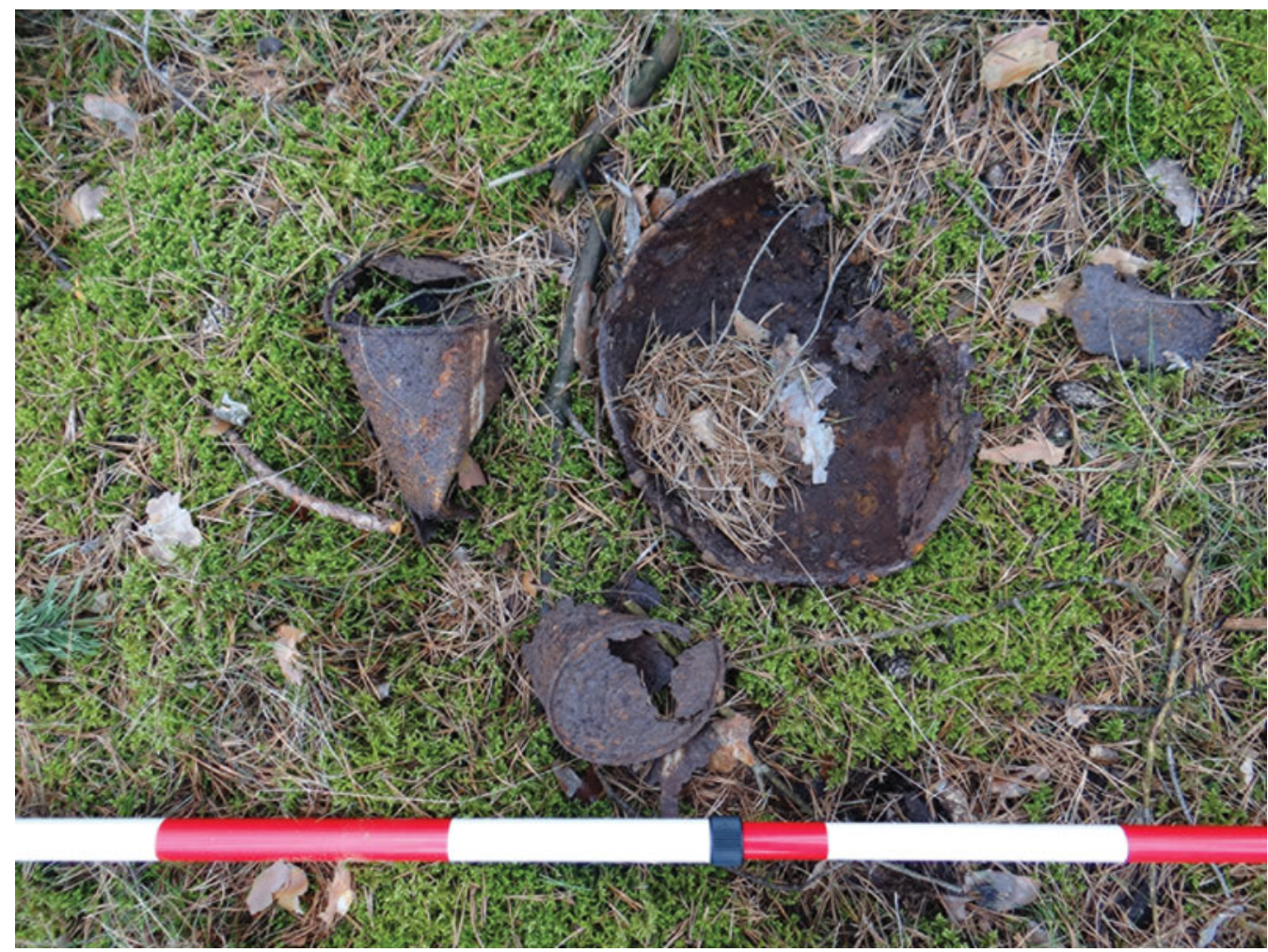

Figure 5. Metal artefacts documented during the research at the camp in Czersk (photograph: Dawid Kobiatka).

\section{A Russian canteen as trench art and its material memory}

During survey of the camp location, many artefacts relating to the day-to-day lives of the prisoners were found and documented. Typical archaeological remains comprised mostly refuse, including broken glass containers for beer, wine, liquor, medicaments and ink, rusted metal vessels, cups, mess tins, tin cans, nails and elements of ovens (Figure 5). Fragments of clay bricks, roofing felt and window glass from the camp's barracks, dugouts and administrative buildings were also recorded. Accordingly, the resulting analysis offers the opportunity to approach how people coped with being detained in a POW camp during the Great War.

Many artefacts associated with the Czersk camp were found accidentally or by looters. Piotr Szulc made one such accidental discovery in 2006 (Figure 6). Although the artefact initially seemed to be an ordinary damaged aluminium vessel, this everyday object turned out to be an intriguing and rare example of Great War trench art.

It should first be noted that 'trench art' does not literally have to be a piece of art found or created in the trenches. On the contrary, as Saunders (2016: 14) claims, the term refers to "any item made by soldiers, prisoners of war and civilians, from war matériel directly, or any other material, as long as it and they are associated temporally and/or spatially with armed conflict or its consequences". What is interesting to highlight there is the fact that trench 


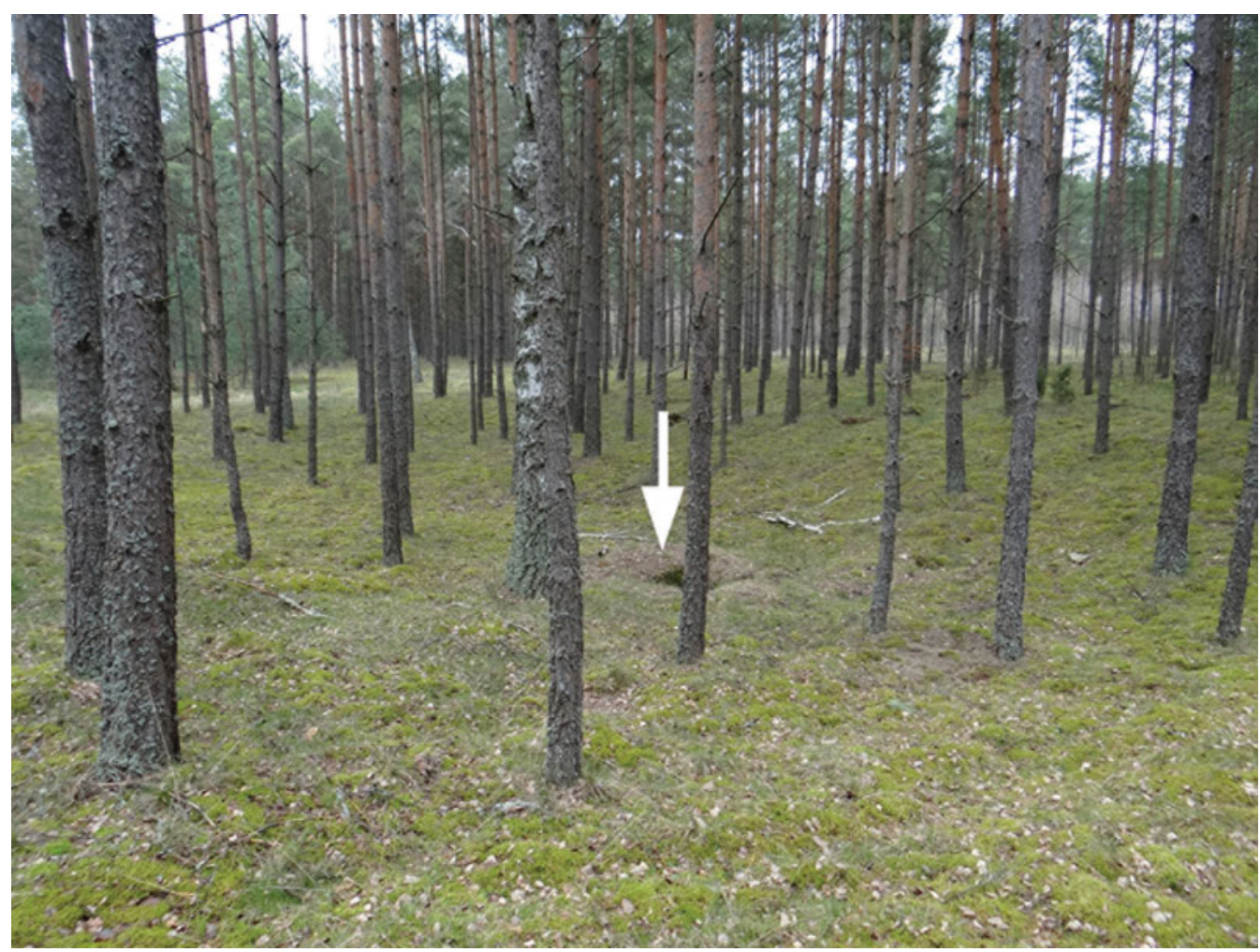

Figure 6. The arrow indicates the place where the canteen was found in 2006 by Piotr Szulc (photograph: Dawid Kobiatka).

art has not been a topic of great interest to Polish archaeologists. Indeed, the author could find no detailed published analyses of, or reference to, trench art in the Polish archaeological literature. In contrast, trench art is an important topic within British archaeology (Saunders 2003, 2016), and it is often pointed out that trench art is a unique category of heritage of the recent past. As Saunders emphasises:

the power of trench art is that it captures the totality of war experience as a threedimensional testament to these experiences, whatever they may be. Fighting, killing, being wounded, souveniring, bartering, elaborating stories, constructing identities and honing reputations are all aspects of conflict. Trench art is a physical manifestation of war, and in its quantity and diversity First World War trench art represents human responses to the intensities and pressures of suffering and survival that so many individuals and families endured between 1914 and 1918, and for decades afterwards. Today, the war is over and the men long gone, but the objects remain, reappraised and revalued as anchors of memory and identity (Saunders 2016: 27).

Canteens were among the objects used by soldiers to express and record their hopes and fears (Hubacz 2017). Military canteens were typically vessels used by soldiers to hold small amounts of liquid (e.g. water, alcohol). The canteen found at Czersk is $135 \mathrm{~mm}$ wide and $225 \mathrm{~mm}$ long (Figure 7 ). The shape and manufacturing marks at the neck of the vessel suggest that the item was produced for the Lyudvig Blumberg and V. Rump (C) Antiquity Publications Ltd, 2018 


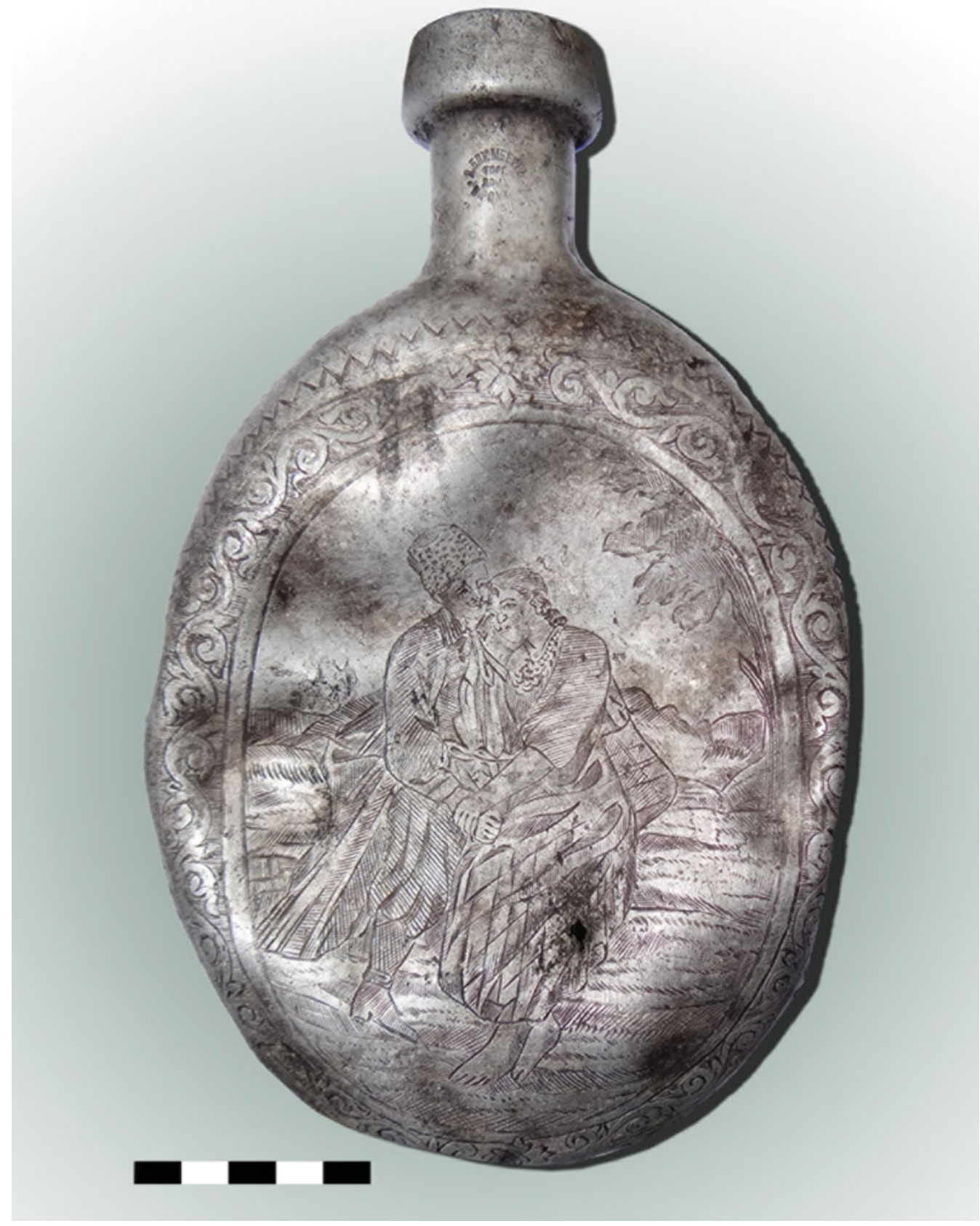

Figure 7. The front side of the canteen (photograph: Dawid Kobiatka). 


\section{Dawid Kobiatka}

(ЛЮДВИГ БЛЮМБЕРГ И В.РОМПЕ) trade house that functioned in Saint Petersburg between 1913 and 1918. During the Great War, Russian soldiers used different types of canteen, some made of thick, colourful glass. Others, such as the canteen from Czersk, were aluminium. Such vessels were an obligatory part of a soldier's equipment, and during the days, weeks, months and years of the war they started to be used to share biographical details of their owners. Specifically, anonymous identical artefacts produced in their tens of thousands quite often, during the conflict, became valuable personal items (Saunders 2003).

The front face of the Czersk canteen displays a scene of a man and a woman embracing and holding hands. The anonymous prisoner who made it expressed many details of

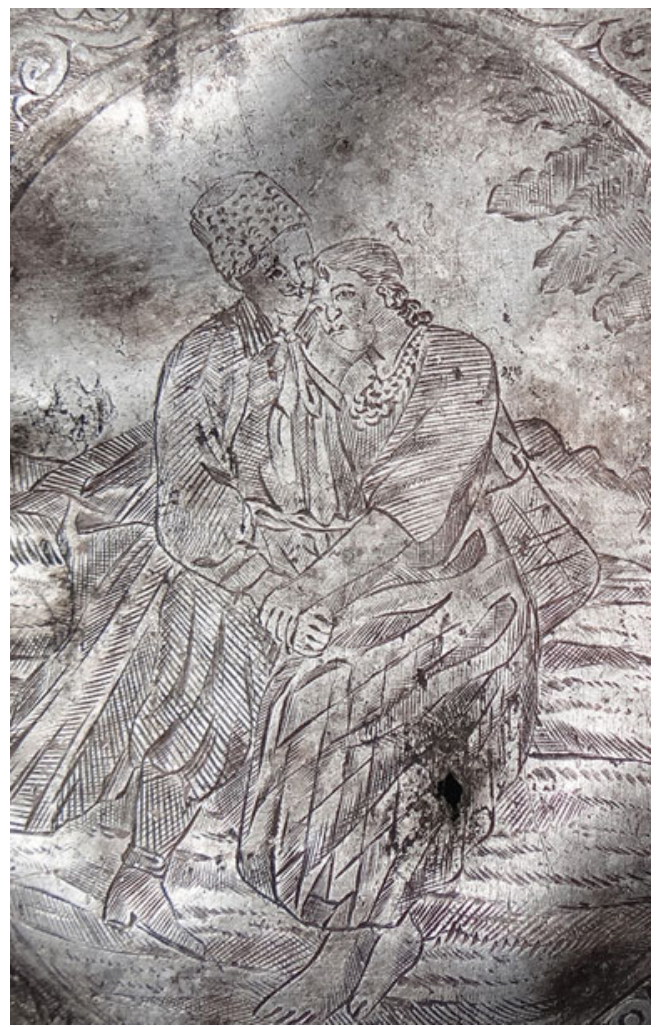

Figure 8. A close-up of the main scene on the canteen (photograph: Dawid Kobiatka). the figures' clothing using different carving techniques (Figure 8). The man has a long, probably expensive robe, comprising more than one element. He is also wearing a coat and a tall, furry hat, and his shoes seem to be made of leather. The hat is very important, as it was of a type typically worn by Cossacks during day-to-day life and was part of their military uniform during the Great War. Photographs and German propaganda postcards show that the Czersk prisoners also wore this type of hat (Figure 1).

The man has big and detailed eyes; the moustache is small but evidently cultivated. The woman is huddled close to the man. She also is wearing expensive clothing and beautiful robes comprised of several different elements. Her neck is decorated with three rows of large beads. She has thick, long hair and, in contrast to her lover, she is barefoot. The pair form the central part of the scene. Behind them is a landscape of arable fields, with a bushy tree growing to the right. The scene is surrounded by floral motifs and a zig-zag carving.

The rear face of the canteen was also carved by the prisoner. In this case, however, the carvings tell another story (Figures $9 \& 10$ ). Rather than creating a pictorial scene, these carvings comprise a few inscribed lines of text. They are written in the Cyrillic alphabet. The first one states: Память Европейко Войны 1914-15-16-19172. [For the memory of the European War 1914-15-16-1917]. Below it are two large, intertwining letters: $O$ and $R$. The last line of the inscription is as follows: Европейской бойны Память плена взят под Корииновым 191515 апреля 1 после дня [As a memento of being taken into (C) Antiquity Publications Ltd, 2018 


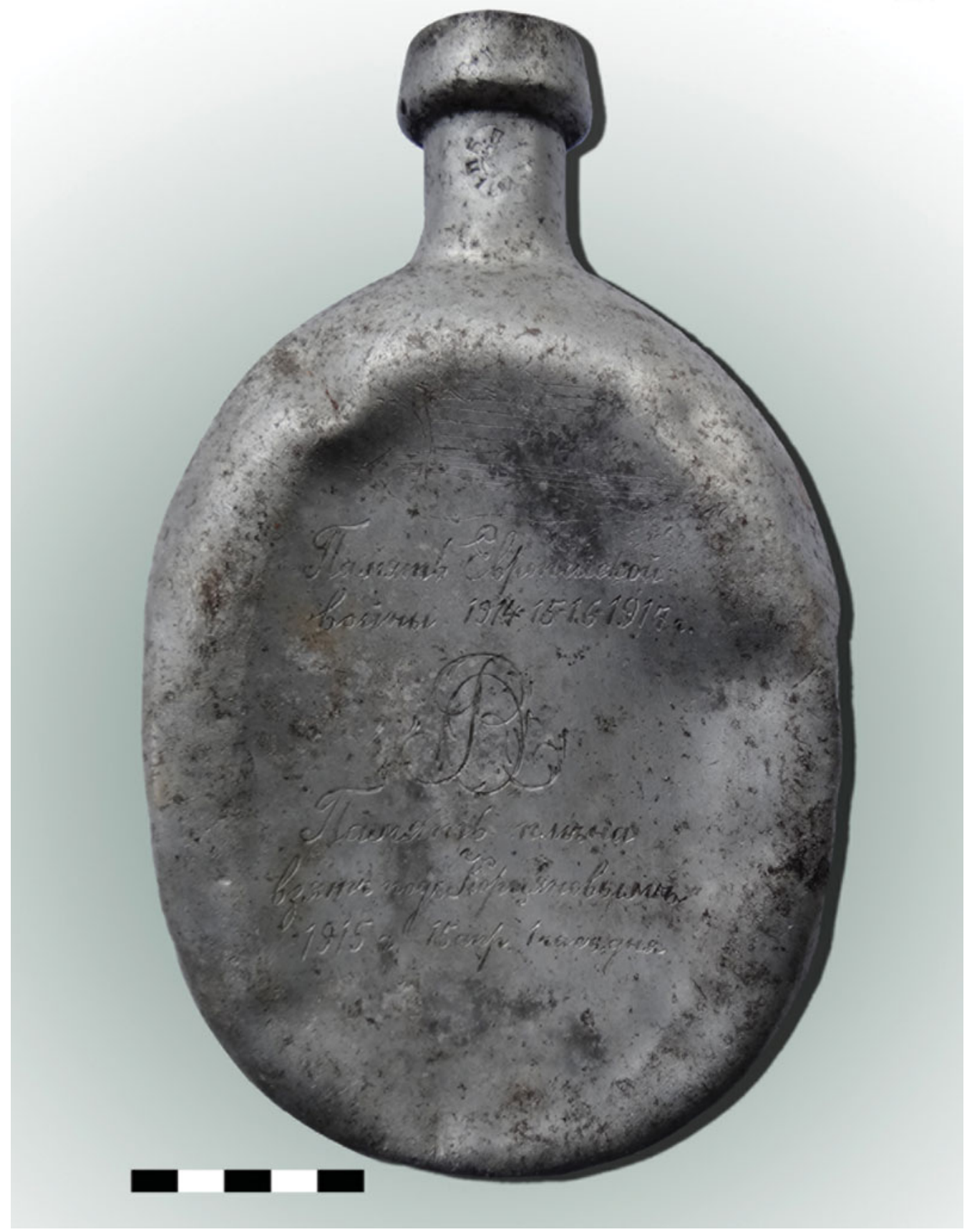

Figure 9. The rear face of the canteen (photograph: Dawid Kobiatka).

(C) Antiquity Publications Ltd, 2018 
captivity at Korajanowo on 15 April 1915]. The last line may be the key to interpreting the artefact and revealing its owner(s), as it commemorates an exact event of the Great War: 15 April 1915, the day when the owner of the canteen was taken into captivity by the enemy (German) troops.

As Saunders $(2003,2016)$ indicates, trench art usually commemorates the personal stories, feelings and fears of the soldier. The same might apply to the Czersk canteen, the carvings on which can be interpreted as
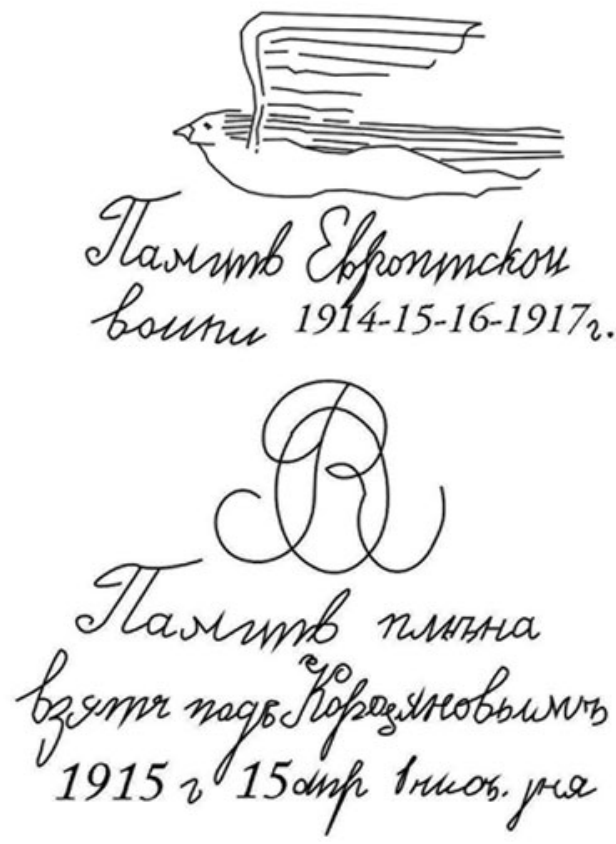

Figure 10. Transcript of the inscription on the rear face of the canteen (prepared by Pawet Stomian and Dawid Kobiatka). a material narration of the memories of a certain nameless Russian prisoner detained at the camp. The letters $O$ and $R$ are most probably the initials of the owner, a soldier in the Russian army. Microscopic analysis of the letters reveal that the $\mathrm{O}$ was carved first. It is most probably the first letter of the name of the soldier, with $\mathrm{R}$ being the first letter of his surname.

The artefact is also a memento ofto use the prisoner's own words-the European War (Европейко Войны). The item records the date and place of the owner's imprisonment. Accordingly, the front face of the canteen might not represent an abstract, unknown and idealised pair of lovers. Although such scenes presenting a rich Cossack and a poor country girl were popular motifs of Eastern European (especially Ukrainian) folklore, a different interpretation is more probable (Vyacheslav Skorokhod pers. comm.).The scene might be a material (and sentimental) memory depicting the owner of the artefact and his sweetheart (perhaps his fiancée or his wife). Many studies indicate how POWs idealised and sentimentalised their lives before imprisonment (Wilkinson 2017).

The life-history of the artefact is more complex and difficult to interpret. The inscriptions are not the only carvings on the rear face of the canteen. Above the first line of the inscription, there is a faint carving depicting a bird. This image was carved using a different technique to the image on the front, and the poorer quality of the image suggests that it was created by a person with less skill and practice. It stands in clear contrast to the scene on the front face and to the inscriptions, which are deep and very precise; a skilled individual must have created them. Questions thus arise: were all of the carvings completed by the same prisoner at the Czersk camp? Was the bird image added later or earlier by another soldier who was detained at the POW camp? Answers to these questions must be purely speculative, yet they indicate the uncertainty and complexity of the life-history of the canteen and its owner(s) as well as of trench art as such. As the latest date on the canteen is 1917, the (C) Antiquity Publications Ltd, 2018 
carvings were probably made in 1917 or 1918 . Hence today, 100 years after their creation, the canteen memorialises the feelings of two anonymous figures from the recent past. Such stories are part of dark (difficult) heritage.

Material remains of the Great War, such as the Czersk canteen, can be interpreted as intimate material memories. These, however, do not have to be just memories of pain and death. Trench art can be considered as a material manifestation and expression of human love, emotions and feelings, of enduring relationships, and of certain events of the Great War. Put simply, the canteen helps to place historic events into a human perspective by focusing on personal items and actual human behaviour (Burström 2009). Such objects add a 'human face' to military material culture. When Burström writes about the 'human face' of military material culture, he uses the term as a metaphor that enriches the understanding of such specific types of material remains. The canteen from Czersk adds an unexpected meaning to this concept. If one assumes that the front side of the canteen depicts its owner then the Burström idea has to be taken literally. Military material culture was also used by soldiers, POWs and civilians as an epitaph for some human beings-indeed, the faces of the man and the woman from the Czersk object are carefully depicted as if the canteen was a mirror of that past reality. That is what makes trench art so powerful and affective.

It took many hours for the Russian soldier(s) to create such meticulous carvings. Each incised line can be seen as representing a deep longing for the beloved person. The canteen complements the dominant historical perspective on twentieth-century warfare. Finally, artefacts such as the canteen make us aware of the significance of the much wider range of emotions within the archaeology of twentieth-century armed conflict. Similarly, the value and meaning of the canteen hinges on the fact that it does not fit into contexts known from other sources, such as the postcards written by soldiers where they describe their life and experiences (e.g. Tomczyszyn 2004). All postcards from the Czersk camp examined by the author were written by German soldiers who were guards at the camp. The POWs are often dehumanised in these postcards. The value and meaning of the canteen is that it commemorates episodes from the life of one of the many victims of the war.

\section{Conclusion}

Archaeological discussions about difficult heritage are in many cases one-sided. Understanding the archaeology of the recent past as a form of research on dark heritage through narratives focused on death, martyrdom and sorrow is a simplification of the broader scope of this research. Material remains of the last global conflicts are multiple and tell different stories, allowing alternative memories of the recent past to be reclaimed.

The material remains of the Great War POW camp at Czersk offer further insights into the dark heritage of the Polish woodlands. Most of that material heritage consists of broken, rusted and decayed objects related to day-to-day life behind barbed wire. One such artefact - the Russian canteen found at the camp in 2006-represents a material memory of human love: behind the carvings stand particular emotions, thoughts, actions and-not least-individual human beings. All of these are part of the history and archaeology of the Great War and show that dark heritage can have its own bright side. 


\section{Dawid Kobiatka}

\section{Acknowledgements}

I would like to thank Piotr Szulc, the discoverer of the canteen, who gave permission to describe the artefact and publish the results. Paweł Słomian, Katarzyna Pyżewicz and Vyacheslav Skorokhod assisted with analysis of the carvings. Thanks are also due to Kornelia Kajda and Mikołaj Kostyrko for joint research on the archaeology of the POW camp at Czersk. Finally, I wish to thank the two anonymous reviewers for their careful reading of the manuscript and their many insightful comments and suggestions. I remain, however, entirely responsible for any simplifications and errors. The work described here is part of my research financed by the National Science Centre, Poland (DEC-2016/20/S/HS3/00001).

\section{References}

Biran, A., Y. Poria \& G. Oren. 2011. Sought experiences at (dark) heritage sites. Annals of Tourist Research 38: 820-41. https://doi.org/10.1016/j.annals.2010.12.001

Burström, M. 2009. Looking into the recent past: extending and exploring the field of archaeology. Current Swedish Archaeology 15-16: 21-36.

CARr, G. \& H. Mytum (ed.). 2012. Cultural heritage and prisoners of war: creativity behind barbed wire. New York: Routledge.

Chęminiak, M. 1999. Piramida pamięci. Gazeta Pomorska, 9 January 1999, p. 14.

GŁoseK, M. (ed.). 2010. Nekropolia z terenu bytego poligonu wojskowego na Brusie w Łodzi. Mogiła ekshumowana w 2008 roku. Łódź: Uniwersytet Łódzki.

González-Ruibal, A. 2014. Archaeology of the contemporary past, in C. Smith (ed.) Encyclopedia of global archaeology: 1683-94. New York: Springer.https://doi.org/10.1007/978-1-44190465-2_1320

Hanson, T.A. 2016. The archaeology of the Cold War. Gainesville: University Press of Florida.

Hesse, R. 2010. LiDAR-derived local relief models-a new tool for archaeological prospection. Archaeological Prospection 17: 67-72. https://doi.org/10.1002/arp.374

Holtorf, C. \& A. Piccini (ed.). 2009. Contemporary archaeologies_excavating now. Frankfurt am Main: Peter Lang.

Hubacz, Ł.J. 2017. Manierki jeńców wojennych 1914-1918 na tle manierek państw zaborczych [Canteens of prisoners of war 1914-1918 compared with the ones of occupying powers]. Mińsk Mazowiecki: Muzeum Ziemi Mińskiej.

Karpus, Z. \& W. Rezmer. 1997. Tuchola. Obóz jeńców i internowanych 1914-1923. Toruń: Wydawnictwo UMK.

KobiaŁka, D., M. Frąckowiak \& K. Kajda. 2015. Tree memories of the Second World War: a case study of common beeches from Chycina, Poland. Antiquity 89: 683-96.

https://doi:10.15184/aqy.2014.52
KobiaŁKa, D., M. Kostyrko \& K. Kajda.2017. The Great War and its landscapes between memory and oblivion: the case of prisoner of war camps in Tuchola and Czersk, Poland. International Journal of Historical Archaeology 21: 134-51. https://doi.org/10.1007/s10761-016-0348-3

Kola, A. 2005. Archeologia zbrodni: oficerowie polscy na cmentarzu ofiar NKWD w Charkowie. Torun: Uniwersytet Mikołaja Kopernika, Rada Ochrony Pamięci Walki i Męczeństwa.

ŁaWrynowicz, O. \& J. ŻElazko (ed.). 2015. Archeologia totalitaryzmu. Ślady represji 1939-1956. Łódź: Instytut Archeologii Uniwersytetu Łódzkiego, Instytut Pamięci Narodowej Komisja Ścigania Zbrodni przeciwko Narodowi Polskiemu Oddział w Łodzi.

Logan, W. \& K. Reeves (ed.). 2009. Places of pain and shame: dealing with 'difficult heritage'. London: Routledge.

Macdonald, S. 2009. Difficult heritage: negotiating the Nazi past in Nuremberg and beyond. London: Routledge.

Marcinkiewicz, A. 2016. Cmentarz obozu jeńców wojennych w Czersku w świetle materiałów archiwalnych ze zbiorów Muzeum Historyczno-Etnograficznego w Chojnicach. Zeszyty Chojnickie 32: 250-59.

Moshenska, G. 2013. The archaeology of the Second World War: uncovering Britain's wartime heritage. Barnsley: Pen \& Sword.

Passmore, D., S. Harrison \& D. Capps Tunwell. 2014. Second World War conflict archaeology in the forests of north-west Europe. Antiquity 88: 1275-90. https://doi.org/10.1017/S0003598X00115455

Rola, J., M. Stasiak \& M. KwiatKowska. 2015. Badania sondażowe na terenie obozu jenieckiego z I wojny światowej w Pile. Wielkopolskie Sprawozdania Archeologiczne 16: 253-58.

SAUNDERs, N. 2003. Trench art: materialities and memories of war. Oxford: Berg.

- 2007. Killing time: archaeology and the First World War. Stroud: Sutton.

(C) Antiquity Publications Ltd, 2018 
- 2016. 'Pearl's Treasure': the trench art collection of an Australian sapper, in L. Slade (ed.) Sappers and shrapnel: contemporary art and the art of the trenches: 12-39. Adelaide: Art Gallery of South Australia.

Schofield, J. 2005. Combat archaeology: material culture and modern conflict. London: Duckworth.

Stichelbaut, B. \& D. Cowley (ed.). 2016. Conflict landscapes and archaeology from above. Farnham: Ashgate.

Stichelbaut, B., W. Gheyle, V.V. Eetvelde, M.V. Meirvenne, T. Saey, N. Note \& H.V. Bourgeois. 2017. The Ypres Salient 1914-1918: historical aerial photography and the landscape of war. Antiquity 91: 235-49. https://doi.org/10.15184/aqy.2016.260
TARLOw, S. 2012. The archaeology of emotion and affect. Annual Review of Anthropology 41: 169-85. https://doi.org/10.1146/annurev-anthro-092611145944

Tomczyszyn, P. 2004. A material link between war and peace: First World War silk postcards, in N. Saunders (ed.) Matters of conflict: material culture, memory and the First World War: 123-33. London: Routledge.

Wilkinson, O. 2017. British prisoners of war in First World War Germany. Cambridge: Cambridge University Press.

Zalewska, A. (ed.). 2016. Archeologia wspótczesności. Warszawa: SNAP.

Received: 29 May 2017; Accepted: 22 August 2017; Revised: 4 September 2017 